\title{
Differences in patients and lesion and procedure characteristics depending on the age of the coronary chronic total occlusion
}

\author{
Krzysztof L. Bryniarski ${ }^{1}$, Gerald S. Werner ${ }^{2}$, Kambis Mashayekhi $^{3}$, Jarosław Wójcik ${ }^{4}$, David Hildick-Smith ${ }^{5}$, \\ George Sianos ${ }^{6}$, Alfredo R. Galassi ${ }^{7}$, Roberto Garbo ${ }^{8}$, Carlo Di Mario ${ }^{9}$, Kamil Fijorek ${ }^{10}$, Nicolas Boudou ${ }^{11}$, \\ Nicolaus Reifart ${ }^{12}$, Leszek Bryniarski ${ }^{13}$
}

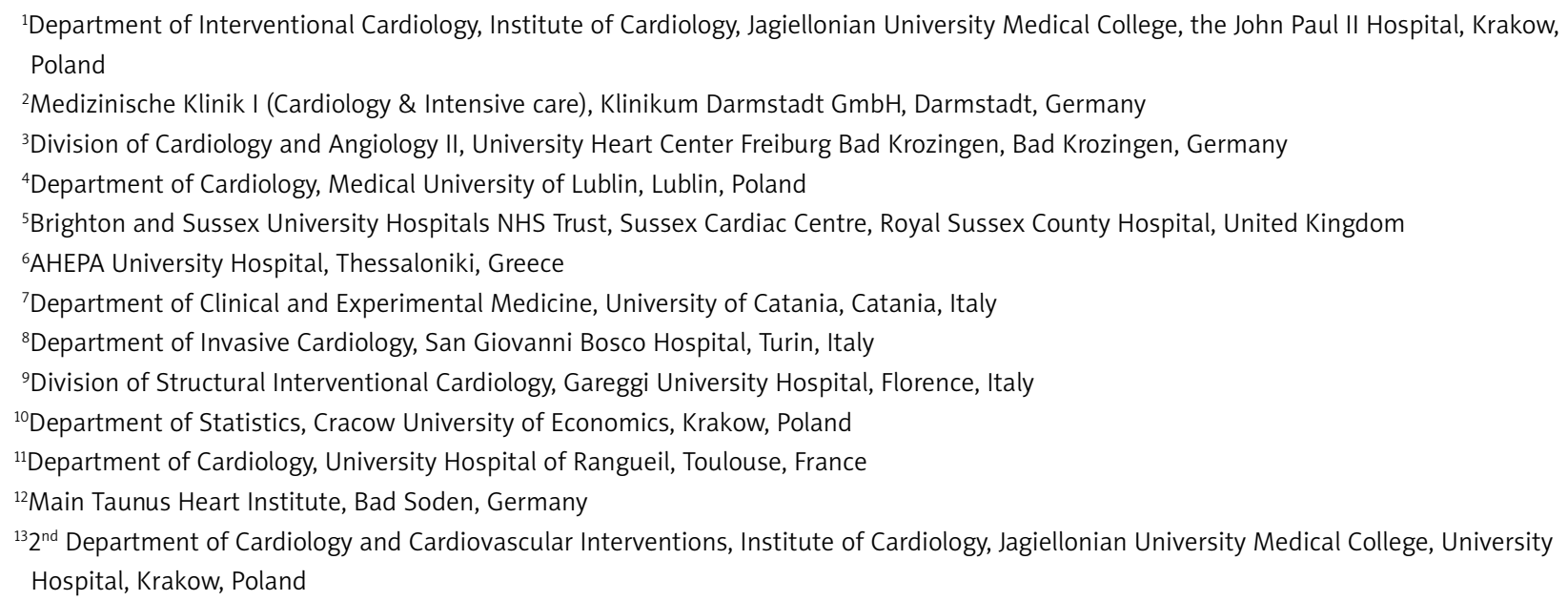

Adv Interv Cardiol 2019; 15, 1 (55): 28-41 DOI: https://doi.org/10.5114/aic.2019.81389

\begin{abstract}
Introduction: Whether duration of chronic total occlusion (СТO) affects lesion and procedural characteristics remains largely unknown.

Aim: To investigate whether CTO duration influences lesion characteristics and revascularization success.

Material and methods: EuroCTO Registry data on patients who had CTO percutaneous coronary intervention between January 2015 and April 2017 were analyzed. Three groups were created based on occlusion age: 3 to 6 months $(n=1415), 7$ to 12 months $(n=973)$, > 12 months $(n=1656)$.

Results: Patients with greater CTO duration were older (63.0 (56.0-70.0); 63.0 (56.0-71.0); 66.0 (59.0-73.0) years respectively; $p<0.001)$, had more 3 -vessel disease (32.2\%; 30.9\%; $46.1 \%$ respectively; $p<0.001$ ) and more frequent prior coronary artery bypass grafting (8.2\%; 9.9\%; 29.4\% respectively; $p<0.001)$. In multivariate analysis, occlusion duration was associated with moderate/ severe calcification $(\mathrm{OR}=1.52 ; 95 \% \mathrm{Cl}: 1.28-1.80 ; p<0.001)$, lesion length $>20 \mathrm{~mm}(\mathrm{OR} 1.77 ; 95 \% \mathrm{Cl} 1.49-2.10 ; p<0.001)$, and collateral circulation Werner type $2(\mathrm{OR}=1.20 ; 95 \% \mathrm{Cl}: 1.01-1.43 ; p=0.041)$. The CTO duration was associated with lower procedural success (OR for success $0.60 ; 95 \% \mathrm{Cl}: 0.46-0.79 ; p<0.001$ ). In multivariate analysis in-hospital adverse events did not differ according to duration of CTO.

Conclusions: Coronary artery CTO duration is associated with greater extent of calcification, lesion length, development of collateral circulation and, most importantly, with lower procedural success.
\end{abstract}

Key words: chronic total occlusion, lesion characteristics, percutaneous coronary intervention.

Su m m a ry

In our study, longer chronic total occlusion (СTO) duration was associated with longer procedure time, greater volume of dye used and lower revascularization success. However, it did not influence the in-hospital adverse event rate. This should be taken into account when planning procedures of СTO older than 12 months. Moreover, in our study longer CTO duration was associated with lower procedural success.

Corresponding author:

Prof. Leszek Bryniarski MD, PhD, Department of Cardiology, Institute of Cardiology, Jagiellonian University Medical College, 17 Kopernika St, 31-501 Krakow, Poland, phone: +48 1242473 00, e-mail: I_bryniarski@poczta.fm

Received: 27.11.2018, accepted: 11.01.2019. 


\section{Introduction}

Chronic total occlusion (СTO) is present in about $16 \%$ to $30 \%$ of patients undergoing coronary angiography [1-3]. Despite the increased experience due to the growth of the number of the performed procedures and the introduction of new techniques and equipment, СTO still remains one of the most demanding procedures in interventional cardiology. Using large registry databases, differences in outcomes and revascularization success in patients with CTO were published during the past years [4-9]. However, as determining age of the CTO may be very challenging, most of them did not include this factor in the analysis. There are several reports describing how and whether CTO duration may affect lesion and procedural characteristics [10-14].

However, none of those studies focused on such a large cohort of patients treated in recent years, and therefore benefiting the most from the latest developments in the field of CTO.

\section{Material and methods}

The European Registry of CTOs (ERCTO) is a prospective real-world monitored based registry involving over 100 centers across Europe including patients treated with CTO percutanous coronary intervention (PCI) [6].

For the purpose of our study we included patients admitted to the hospitals between January 2015 and the end of April 2017. The treatment indication for CTO was symptomatic myocardial ischemia and/or evidence of reversible myocardial ischemia by perfusion imaging or stress testing. Registry data from both members and associates of the Euro CTO Club were included. Only patients with certain or likely CTO duration were included in the analysis. Out of 10699 patients in the database recruited during the selected period of time, 5933 patients were excluded due to undetermined age of the occlusion. Out of the remaining 4766 patients we excluded $287 \mathrm{pa}$ tients with an additional acute coronary syndrome and 435 patients with insufficient further data regarding the occlusion characteristics. In the end, a total of 4044 patients were included in the data analysis (Figure 1). Patients were divided into 3 groups according to age of the CTO: 1) 3-6 months; 2) 7-12 months; 3) over 12 months.

Coronary CTO was defined as angiographic evidence of total occlusions with thrombolysis in myocardial infarction (TIMI) flow grade of 0 and estimated duration of at least 3 months. The length of coronary occlusions was estimated from angiographic projections. Degree of calcification was estimated visually on fluoroscopy. Moderate and severe calcifications were defined as calcium extending for less than half or equal/greater than half of the total CTO segment, respectively. The assessment of collateral connections was made according to the Werner classification (CC) [15]. Occlusion duration in the ERCTO was divided into 3 levels of certainty (cer- tain and angiographically confirmed; likely and clinically confirmed; undetermined), as suggested by the Euro CTO Club consensus document [16]. Procedural success was defined as angiographic success (final residual stenosis < $30 \%$ by visual estimation and TIMI flow grade of 3 after CTO recanalization). In-hospital adverse events (AEs) were defined as the composite of non-Q-wave and Q-wave myocardial infarction (MI), coronary perforation requiring intervention, recurrent angina requiring urgent repeat revascularization with $\mathrm{PCl}$ or coronary bypass surgery, major bleeding, stent thrombosis, stroke, and death. The complexity of CTO lesion was assessed through the J-CTO (Multicenter CTO Registry in Japan) score and the clinical and lesion-related (CL) score $[17,18]$.

\section{Statistical analysis}

Categorical variables are presented as counts and percentages (\%). The median $\left(25^{\text {th }}-75^{\text {th }}\right.$ percentiles) is reported for continuous data. Fisher's exact test or $\chi^{2}$ test was used for categorical variables, and the Mann-Whitney $U$ test was used to compare continuous variables. Multivariable logistic regression analyses were performed to determine the independent predictors for lesion and procedural characteristics. Univariate analysis was performed for all variables in the study, then the variables with $p<0.05$ were included in the multivariable models for adjusted analysis. Statistical analyses were performed with R 3.4 .

\section{Results}

A total of 4044 of patients were included in the main analysis. Patients with the longest CTO duration as compared to patients with CTO duration 3-6 months were

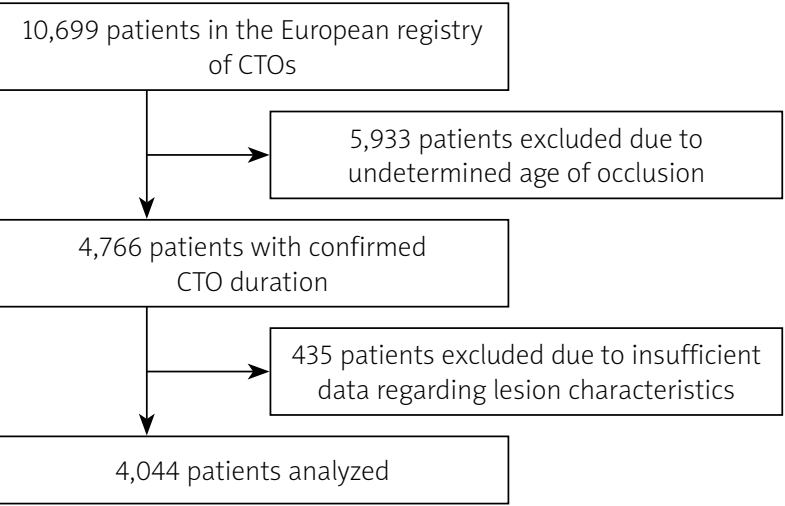

Figure 1. Flow chart. Out of 10699 patients in the database recruited during the selected period of time, 5933 patients were excluded due to undetermined age of the occlusion. Out of the remaining 4766 patients we excluded 287 patients with an additional acute coronary syndrome and 435 patients with insufficient further data regarding the occlusion characteristics. In the end a total of 4044 patients were included in the data analysis 
significantly older (63.0 (56.0-70.0) vs. 66.0 (59.0-73.0) years) and had higher prevalence of peripheral artery disease (8.8\% vs. $12.4 \%)$ (Table I). The group with the longest CTO duration had higher incidence of myocardial infarction (MI) and prior coronary artery bypass grafting $(\mathrm{CABG})$ as compared to other groups. Lesion and pro-

Table I. Clinical characteristics of patients depending on the chronic total occlusion age

\begin{tabular}{|c|c|c|c|c|}
\hline Parameter & $\begin{array}{c}3-6 \text { months } \\
(n=1415)\end{array}$ & $\begin{array}{c}7-12 \text { months } \\
(n=973)\end{array}$ & $\begin{array}{c}>12 \text { months } \\
(n=1656)\end{array}$ & Overall $p$-value \\
\hline Age [years] & $63.0(56.0-70.0)$ & $63.0(56.0-71.0)$ & $66.0(59.0-73.0)$ & $<0.001$ \\
\hline Gender (male), $n(\%)$ & $1197(84.7)$ & $812(83.5)$ & $1440(87.0)$ & 0.030 \\
\hline $\mathrm{BMI}\left[\mathrm{kg} / \mathrm{m}^{2}\right]$ & $27.8(25.3-31.1)$ & $27.8(25.3-31.1)$ & $28.3(25.6-31.1)$ & 0.077 \\
\hline Hypertension, $n$ (\%) & $1097(77.5)$ & 787 (80.9) & $1369(82.7)$ & 0.002 \\
\hline Diabetes, $n(\%)$ & $426(31.8)$ & $288(31.6)$ & $539(35.4)$ & 0.062 \\
\hline Hypercholesterolemia, $n$ (\%) & $1137(80.4)$ & $762(78.3)$ & $1317(79.5)$ & 0.479 \\
\hline Smokers, $n(\%)$ & $334(25.0)$ & $220(24.1)$ & $299(19.6)$ & 0.001 \\
\hline $\mathrm{PAD}, n(\%)$ & $124(8.8)$ & $98(10.1)$ & $206(12.4)$ & 0.004 \\
\hline Previous MI, $n$ (\%) & $557(40.0)$ & $394(41.1)$ & $818(51.2)$ & $<0.001$ \\
\hline Previous CABG, $n$ (\%) & $116(8.2)$ & $96(9.9)$ & $486(29.4)$ & $<0.001$ \\
\hline Previous PCI, $n(\%)$ & $682(48.2)$ & $481(49.4)$ & $913(55.2)$ & $<0.001$ \\
\hline $\mathrm{GFR}\left[\mathrm{ml} / \mathrm{min} / 1.73 \mathrm{~m}^{2}\right]$ & $91.2(70.4-111.3)$ & $91.2(71.6-112.2)$ & $84.0(66.7-108.2)$ & $<0.001$ \\
\hline Left ventricular EF <35, $n(\%)$ & $78(5.5)$ & $49(5.1)$ & $120(7.3)$ & 0.039 \\
\hline 3-vessel disease, $n(\%)$ & $449(32.2)$ & $294(30.9)$ & $749(46.1)$ & $<0.001$ \\
\hline
\end{tabular}

Values are median $\left(25^{\text {th }}-75^{\text {th }}\right.$ percentile) or $n(\%)$. BMI - body mass index, CABG - coronary artery bypass grafting, EF-ejection fraction, GFR - glomerular filtration rate, $\mathrm{MI}$ - myocardial infarction, $P A D$ - peripheral artery disease, $P C l$ - percutaneous coronary intervention.

Table II. Lesion characteristics depending on the chronic total occlusion age

\begin{tabular}{|c|c|c|c|c|}
\hline Parameter & $\begin{array}{l}3-6 \text { months } \\
(n=1415)\end{array}$ & $\begin{array}{l}7-12 \text { months } \\
(n=973)\end{array}$ & $\begin{array}{l}>12 \text { months } \\
(n=1656)\end{array}$ & Overall $p$-value \\
\hline СTO artery & & & & 0.001 \\
\hline RCA, $n(\%)$ & $773(54.7)$ & $545(56.0)$ & $998(60.3)$ & \\
\hline LM, $n(\%)$ & $6(0.4)$ & $5(0.5)$ & $19(1.1)$ & \\
\hline LAD, $n(\%)$ & $393(27.8)$ & $250(25.7)$ & $342(20.7)$ & \\
\hline$C x, n(\%)$ & $235(16.6)$ & $168(17.3)$ & $288(17.4)$ & \\
\hline СTO in bypass, $n(\%)$ & $5(0.4)$ & $5(0.5)$ & $8(0.5)$ & \\
\hline Ostial CTO, $n$ (\%) & $154(10.9)$ & $102(10.5)$ & $254(15.4)$ & $<0.001$ \\
\hline Vessel diameter $[\mathrm{mm}]$ & $3.0(2.5-3.0)$ & $3.0(2.7-3.0)$ & $3.0(2.7-3.0)$ & 0.006 \\
\hline CTO length $[\mathrm{mm}]$ & $20.0(15.0-30.0)$ & $25.0(15.0-30.0)$ & $28.0(20.0-40.0)$ & $<0.001$ \\
\hline Collateral circulation type $2, n(\%)$ & $333(24.7)$ & $274(29.5)$ & $474(30.1)$ & 0.002 \\
\hline Proximal tortuosity, $n(\%)$ & $271(19.4)$ & $162(16.9)$ & $332(20.6)$ & 0.073 \\
\hline In CTO bend, $n(\%)$ & $388(27.5)$ & $330(34.2)$ & $614(37.3)$ & $<0.001$ \\
\hline $\begin{array}{l}\text { Moderate and severe calcification, } \\
n(\%)\end{array}$ & $486(34.4)$ & $370(38.3)$ & $851(51.6)$ & $<0.001$ \\
\hline Blunt stump, $n(\%)$ & $610(43.3)$ & $405(41.7)$ & $734(44.5)$ & 0.366 \\
\hline Severe distal disease, $n(\%)$ & $475(34.5)$ & $353(38.0)$ & $783(48.8)$ & $<0.001$ \\
\hline
\end{tabular}

Values are median $\left(25^{\text {th }}-75^{\text {th }}\right.$ percentile) or $n(\%)$. CTO - chronic total occlusion, CX - circumflex artery, LAD - left anterior descending artery, LM - left main artery, $R C A$ - right coronary artery. 
Table III. Procedural characteristics depending on the chronic total occlusion age

\begin{tabular}{lcccc} 
Parameter & $\begin{array}{c}3-6 \text { months } \\
(n=1415)\end{array}$ & $\begin{array}{c}7-12 \text { months } \\
(n=973)\end{array}$ & $\begin{array}{c}>12 \text { months } \\
(n=1656)\end{array}$ & Overall $p$-value \\
\hline $\begin{array}{l}\text { One or more previous attempts, } \\
n(\%)\end{array}$ & $470(33.2 \%)$ & $319(32.8 \%)$ & $563(34.0 \%)$ & 0.789 \\
\hline Retrograde approach, $n(\%)$ & $342(24.2 \%)$ & $237(24.4 \%)$ & $638(38.5 \%)$ & $<0.001$ \\
\hline Procedural failure, $n(\%)$ & $112(7.9 \%)$ & $109(11.2 \%)$ & $273(16.5 \%)$ & $<0.001$ \\
\hline AE, $n(\%)$ & $29(2.0 \%)$ & $24(2.5 \%)$ & $60(3.6 \%)$ & 0.024 \\
\hline Procedure time & $85.0(57.0-120.0)$ & $90.0(63.0-127.0)$ & $120.0(77.0-162.0)$ & $<0.001$ \\
\hline Fluoroscopy time & $31.5(19.0-53.0)$ & $32.5(20.0-52.0)$ & $45.0(27.0-70.0)$ & $<0.001$ \\
\hline Dye used & $237.0(170.0-330.0)$ & $250.0(170.0-350.0)$ & $250.0(190.0-350.0)$ & $<0.001$
\end{tabular}

Values are median $\left(25^{\text {th }}-75^{\text {th }}\right.$ percentile) or $n(\%)$. AE-adverse events.

cedural characteristics also differed between patients with different age of the CTO (Tables II, III). Patients with the longest CTO duration as compared to patients with CTO duration 3-6 months had longer occlusions (28.0 (20.0-40.0) vs. $20.0(15.0-30.0) \mathrm{mm})$, more calcified lesions (calcification moderate or severe; $51.6 \%$ vs. $34.4 \%$ ), better collateral circulation (30.1\% vs. $24.7 \%$ for CC2) and more advanced coronary artery disease distal to CTO (48.8\% vs. $34.5 \%)$. The revascularization success rate was the highest in the patients with CTO duration 3-6 months as compared to the patients with the oldest CTO (92.1\% vs. $83.5 \%)$, and the retrograde approach was

A

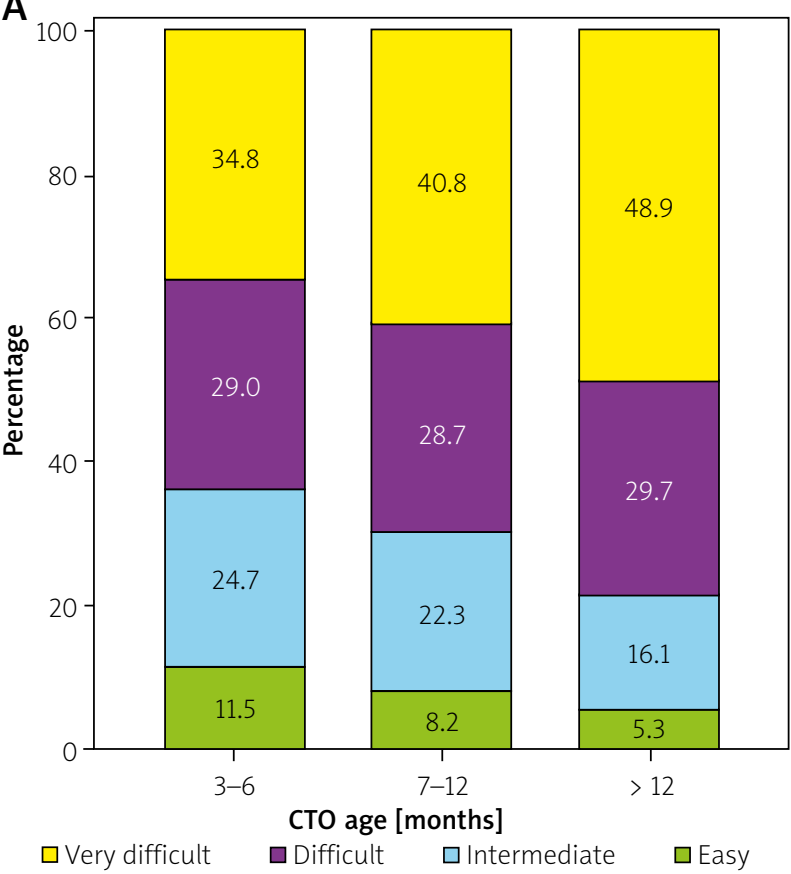

less common in those lesions (24.2\% vs. $38.5 \%)$. Intravascular ultrasound was used more frequently in the older occlusions (15.7\% vs. 9.5\%). Incidence of in-hospital AEs increased from $2.0 \%$ in the group with the shortest CTO duration to $3.6 \%$ in the group with the longest CTO duration (Table III). Time of the procedure and dye volume increased significantly with increased CTO duration, reaching up to $120 \mathrm{~min}$ and $250 \mathrm{ml}$ of dye used in the last group (Table III). The J-CTO score as well as the CL score were higher in older lesions (Figure 2).

In multivariate analysis (univariate analysis is presented in Table IV) we found that CTO duration was an

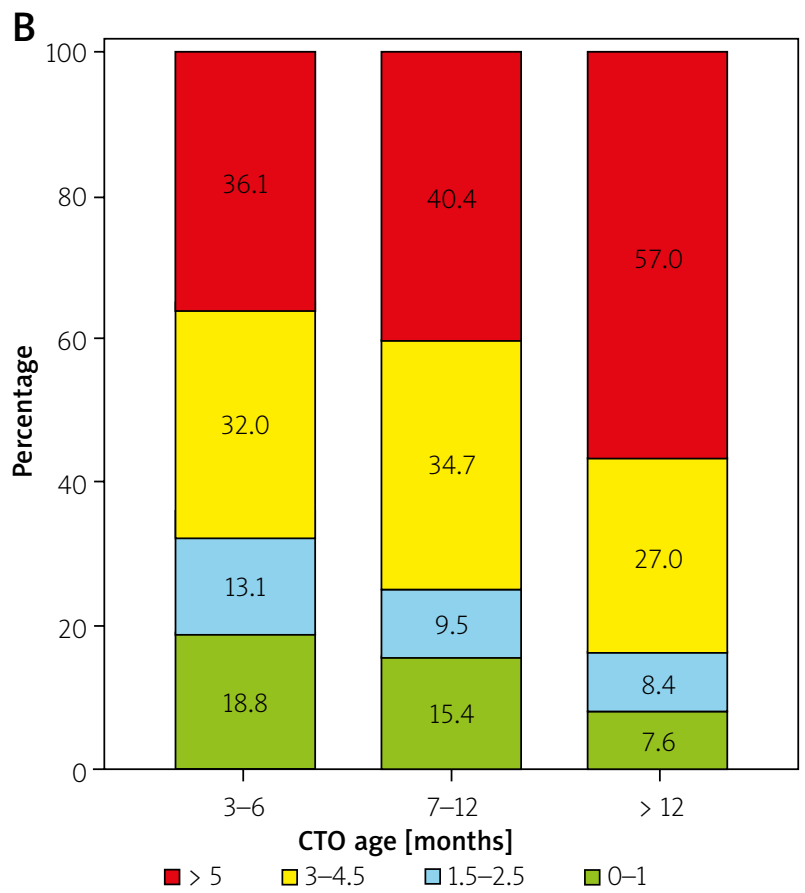

Figure 2. Differences in J-CTO score (A) and CL score (B) depending on the chronic total occlusion age. Differences in J-CTO score between patients with different chronic total occlusion (CTO) duration were significant (3968 patients; $p$ < 0.001). J-CTO score of 3 or more increased with increase of the lesion age. In the CL score only patients with a first attempt were included in the analysis (2692 patients). Differences in CL score depending on the occlusion duration were significant $(p<0.001)$ and prevalence of a CL score of more than 5 points increased with the lesion age 
independent predictor of lesion length, severity of calcification, better developed collateral circulation and procedure failure, but it did not influence the $A E$ rate (Table $V$ ). Full multivariate analysis is presented in Table VI.

Differences between patients with undetermined age of the occlusion and known occlusion duration are presented in the Supplement (Table VII). As expected, patients with determined age of occlusion had previous MI and CABG more frequently $(37.5 \%$ vs. $44.8 \%$ and $8.1 \%$ vs. $17.3 \%$ respectively). The procedural failure rate was similar in both groups (11.9\% vs. $12.2 \%)$. Interestingly, incidence of AEs was higher in the group with undetermined age of the occlusion (3.7\% vs. $2.8 \%$ ).

\section{Discussion}

Our study, performed on a large cohort of patients, demonstrated that: 1) longer duration of CTO is associated with longer procedure and fluoroscopy time, and greater amount of dye used; 2) longer duration of CTO is a predictor of greater calcification, longer lesions and more developed collateral circulation; 3) age of the CTO influences the procedure success, but not in-hospital AEs.

\section{Procedure duration}

As observed in previous studies, patients with longer CTO duration had longer procedure and fluoroscopy time, as well as a greater amount of dye used [10]. These results should be taken into account when planning a procedure with known age of the CTO.

\section{Calcification}

In our study occlusion duration of over 12 months was an independent predictor of calcification. In more advanced coronary artery disease (CAD), elevated lipid content and inflammatory mediators induce osteogenic differentiation of vascular smooth muscle cells in the intima - usually calcific deposits are found more frequently and in greater amounts among more advanced lesions and in elderly individuals [19]. These observations were confirmed in the CTO histopathology study where older lesion age was associated with a greater fibrocalcific component [20]. Comparable to our results, Danek et al. recently observed a difference of $16 \%$ in moderate/severe calcification between patients with a CTO duration shorter than 5 and longer than 36.3 months [10]. Moreover, as previously reported, CABG in medical history was also associated with higher prevalence of calcification in CTO lesions [21]. Importantly, calcification is regarded as one of the predictors of failure when performing $\mathrm{PCl}$ of CTO - both the CL score proposed by Alessandrino et al. and the J-CTO score include calcification in their scoring systems $[17,18]$.

\section{Collateral circulation}

We observed that occlusion duration longer than 6 months was a predictor of development of collaterals in CC grade 2 proposed by Werner et al. [15]. Time of recruitment of collaterals in CTO is still debatable, ranging from several weeks to months [22]. Collateral flow plays several major roles in CTO. First, well-developed collaterals have the capacity to prevent myocardial necrosis and may preserve myocardial viability [22]. Second, collaterals are used during the retrograde approach and thus poorly developed collaterals were found to be an independent predictor of technical failure in CTO $\mathrm{PCl}[5,23]$.

\section{Lesion length}

In contrast to the study of Danek et al., we found that CTO length increased with age of the CTO [10]. In our study, even occlusion duration longer than 6 months was an independent predictor of CTO length over $20 \mathrm{~mm}$. One could speculate that with the novel techniques including the hybrid approach and retrograde revascularization lesion length may be less important in assessing complexity of the CTO procedures as shown in the PROGRESS CTO score and ORA score [5, 23]. In contrast, Ellis et al. showed in their recent study assessing predictors of a successful hybrid approach that procedure failure is correlated with occlusion length over $10 \mathrm{~mm}$ [7]. Besides that, longer lesions may still influence the duration of the procedure [17].

\section{Procedural success}

Currently several different angiographic scoring systems assessing predictors of failure and success in CTO $\mathrm{PCl}$ are available, but none of them has ever included the duration of CTO in their analysis [24-26]. On the other hand, CTO duration as predictor of revascularization failure has been described in computed tomography studies $[13,14]$. Given the results of those studies and our current study, it is plausible to say that duration of CTO may have an influence on procedural success and PCI of CTO should not be postponed, although this observation merits further research. Nevertheless, it should be underlined that in our study the exact age of CTO lesions could only be determined in less than $50 \%$ of the cases; thus implementing CTO duration in future scoring systems may be challenging. Lastly, some of the studies did not find a correlation between CTO duration and procedural success; however, the number of patients included in the analysis was also significantly lower [27].

\section{Adverse events}

A weighted meta-analysis by Patel et al. with 18061 patients included from 65 studies revealed low rates of AEs in patients undergoing $\mathrm{CTO} \mathrm{PCI}$ [2]. In our study rates of AEs were comparable, with $0.4 \%$ deaths and $0.7 \% \mathrm{MI}$ 
Table IV. Univariate analysis for lesion characteristics

\begin{tabular}{|c|c|c|c|}
\hline Parameter & $\begin{array}{l}\text { Moderate/severe calcification } \\
\qquad(n=2320)\end{array}$ & $\begin{array}{l}\text { Mild/no calcification } \\
\quad(n=1701)\end{array}$ & $P$-value \\
\hline Age [years] & $63.0(55.0-70.0)$ & $66.0(59.0-74.0)$ & $<0.001$ \\
\hline Gender (male), $n(\%)$ & $1961(84.6)$ & $1472(86.3)$ & 0.139 \\
\hline $\mathrm{BMI}\left[\mathrm{kg} / \mathrm{m}^{2}\right]$ & $27.8(25.4-31.1)$ & $28.1(25.5-31.2)$ & 0.135 \\
\hline Hypertension, $n(\%)$ & $1808(77.9)$ & $1435(84.1)$ & $<0.001$ \\
\hline Hypercholesterolemia, $n(\%)$ & $1819(78.4)$ & $1385(81.1)$ & 0.037 \\
\hline Diabetes, $n(\%)$ & $640(29.5)$ & $609(38.4)$ & $<0.001$ \\
\hline Smoker, $n(\%)$ & $544(25.1)$ & $305(19.2)$ & $<0.001$ \\
\hline PAD, $n(\%)$ & $187(8.1)$ & $239(14.0)$ & $<0.001$ \\
\hline COPD, $n(\%)$ & $85(3.7)$ & $110(6.4)$ & $<0.001$ \\
\hline Prior stroke, $n(\%)$ & $64(2.8)$ & $45(2.6)$ & \\
\hline Previous MI, $n(\%)$ & $1047(45.9)$ & $714(43.2)$ & 0.1 \\
\hline Previous CABG, $n(\%)$ & $269(11.6)$ & $426(25.0)$ & $<0.001$ \\
\hline Previous $\mathrm{PCI}, n(\%)$ & $1144(49.3)$ & $922(54.0)$ & 0.004 \\
\hline GFR $\left[\mathrm{ml} / \mathrm{min} / 1.73 \mathrm{~m}^{2}\right]$ & $91.2(71.5-113.6)$ & $84.2(65.5-107.2)$ & $<0.001$ \\
\hline Left ventricular EF <35\%, $n(\%)$ & $143(6.2)$ & $103(6.1)$ & 0.91 \\
\hline Number of diseased vessels, $n(\%)$ : & & & $<0.001$ \\
\hline 1 -vessel disease & $823(36.2)$ & $392(23.3)$ & \\
\hline 2-vessel disease & $736(32.4)$ & $514(30.6)$ & \\
\hline 3-vessel disease & 715 (31.4) & $773(46.0)$ & \\
\hline CTO artery, $n$ (\%): & & & $<0.001$ \\
\hline RCA & $1248(53.9)$ & $1061(62.2)$ & \\
\hline LAD & $597(25.8)$ & $383(22.4)$ & \\
\hline$C x$ & $451(19.5)$ & $235(13.8)$ & \\
\hline LM & $3(0.1)$ & $27(1.6)$ & \\
\hline СTO in bypass & $17(0.7)$ & $1(0.1)$ & \\
\hline CTO in side branch & $78(3.4)$ & $34(2.0)$ & 0.012 \\
\hline Ostial CTO & $227(9.8)$ & $281(16.5)$ & $<0.001$ \\
\hline Occlusion duration, $n$ (\%): & & & $<0.001$ \\
\hline $3-6$ months & $486(28.5)$ & $925(39.9)$ & \\
\hline $7-12$ months & $370(21.7)$ & $596(25.7)$ & \\
\hline Over 12 months & $851(49.9)$ & $799(34.4)$ & \\
\hline Parameter & $\begin{array}{c}\text { CC2 } \\
(n=2772)\end{array}$ & $\begin{array}{l}\mathrm{CC} 0 / \mathrm{CC} 1 \\
(n=1081)\end{array}$ & $P$-value \\
\hline Age [years] & $64.0(57.0-72.0)$ & $64.0(57.0-72.0)$ & 0.917 \\
\hline Gender (male), $n(\%)$ & $2331(84.2)$ & $951(88.0)$ & 0.003 \\
\hline $\mathrm{BMI}\left[\mathrm{kg} / \mathrm{m}^{2}\right]$ & $28.1(25.4-31.1)$ & $27.8(25.4-31.1)$ & 0.372 \\
\hline Hypertension, $n(\%)$ & $2236(80.7)$ & $864(79.9)$ & 0.636 \\
\hline Hypercholesterolemia, $n(\%)$ & $2206(79.6)$ & $859(79.5)$ & 0.97 \\
\hline Diabetes, $n(\%)$ & $878(33.7)$ & $308(30.7)$ & 0.087 \\
\hline Smoker, $n(\%)$ & $592(22.7)$ & $231(23.0)$ & 0.9 \\
\hline $\mathrm{PAD}, n(\%)$ & $282(10.2)$ & $127(11.7)$ & 0.171 \\
\hline COPD, $n(\%)$ & $133(4.8)$ & $57(5.3)$ & 0.597 \\
\hline Prior stroke, $n(\%)$ & $71(2.6)$ & $34(3.1)$ & 0.373 \\
\hline Previous MI, $n(\%)$ & $1214(44.8)$ & $464(44.1)$ & 0.743 \\
\hline Previous CABG, $n(\%)$ & $448(16.2)$ & $214(19.8)$ & 0.008 \\
\hline Previous PCI, $n(\%)$ & $1428(51.5)$ & $550(50.9)$ & 0.742 \\
\hline GFR $\left[\mathrm{ml} / \mathrm{min} / 1.73 \mathrm{~m}^{2}\right]$ & $89.0(68.8-110.7)$ & $89.1(69.8-111.3)$ & 0.5 \\
\hline Left ventricular EF < 35\%, $n(\%)$ & $182(6.6)$ & $48(4.5)$ & 0.018 \\
\hline
\end{tabular}


Table IV. Cont.

\begin{tabular}{|c|c|c|c|}
\hline Parameter & $\begin{array}{c}\text { CC2 } \\
(n=2772)\end{array}$ & $\begin{array}{l}\text { CCO/CC1 } \\
(n=1081)\end{array}$ & $P$-value \\
\hline Number of diseased vessels, $n(\%)$ : & & & $<0.001$ \\
\hline 1-vessel disease & $790(28.9)$ & $372(35.4)$ & \\
\hline 2-vessel disease & $873(32.0)$ & $323(30.7)$ & \\
\hline 3-vessel disease & $1067(39.1)$ & 357 (33.9) & \\
\hline CTO artery, $n(\%):$ & & & $<0.001$ \\
\hline RCA & $1555(56.2)$ & $681(63.0)$ & \\
\hline LAD & $666(24.1)$ & $261(24.1)$ & \\
\hline $\mathrm{Cx}$ & $521(18.8)$ & $126(11.7)$ & \\
\hline$L M$ & $14(0.5)$ & $12(1.1)$ & \\
\hline СТO in bypass & $12(0.4)$ & $1(0.1)$ & \\
\hline СTO in side branch & $96(3.5)$ & $10(0.9)$ & $<0.001$ \\
\hline Ostial CTO & $330(11.9)$ & $163(15.2)$ & 0.008 \\
\hline Occlusion duration, $n$ (\%): & & & 0.003 \\
\hline $3-6$ months & $333(30.8)$ & $1013(36.5)$ & \\
\hline $7-12$ months & $274(25.3)$ & $656(23.7)$ & \\
\hline Over 12 months & $474(43.8)$ & $1103(39.8)$ & \\
\hline Parameter & $\begin{array}{c}\text { Lesion length }<20 \mathrm{~mm} \\
(n=1167)\end{array}$ & $\begin{array}{c}\text { Lesion length }>20 \mathrm{~mm} \\
(n=2832)\end{array}$ & $P$-value \\
\hline Age [years] & $65.0(58.0-73.0)$ & $64.0(57.0-71.0)$ & 0.015 \\
\hline Gender (male), $n$ (\%) & $973(83.4)$ & $2438(86.1)$ & 0.034 \\
\hline $\mathrm{BMI}\left[\mathrm{kg} / \mathrm{m}^{2}\right]$ & $27.8(25.3-30.8)$ & $28.0(25.5-31.2)$ & 0.032 \\
\hline Hypertension, $n(\%)$ & $930(79.7)$ & $2287(80.8)$ & 0.467 \\
\hline Hypercholesterolemia, $n$ (\%) & $944(80.9)$ & $2237(79.0)$ & 0.19 \\
\hline Diabetes, $n(\%)$ & $356(32.3)$ & $885(33.7)$ & 0.45 \\
\hline Smoker, $n(\%)$ & $233(21.2)$ & $614(23.4)$ & 0.155 \\
\hline PAD, $n(\%)$ & $100(8.6)$ & $322(11.4)$ & 0.01 \\
\hline COPD, $n(\%)$ & $51(4.4)$ & $144(5.1)$ & 0.383 \\
\hline Prior stroke, $n(\%)$ & $32(2.7)$ & $78(2.8)$ & 1 \\
\hline Previous MI, $n(\%)$ & $471(41.2)$ & $1282(46.4)$ & 0.003 \\
\hline Previous CABG, $n(\%)$ & $163(14.0)$ & $524(18.5)$ & 0.001 \\
\hline Previous PCI, $n(\%)$ & $551(47.2)$ & $1497(52.9)$ & 0.001 \\
\hline GFR $\left[\mathrm{ml} / \mathrm{min} / 1.73 \mathrm{~m}^{2}\right]$ & $87.0(68.5-108.2)$ & $89.2(69.1-111.4)$ & 0.159 \\
\hline Left ventricular EF <35\%, $n(\%)$ & $68(5.9)$ & $178(6.3)$ & 0.629 \\
\hline Number of diseased vessels, $n(\%)$ : & & & 0.044 \\
\hline 1 -vessel disease & $372(32.6)$ & $838(30.1)$ & \\
\hline 2-vessel disease & $376(32.9)$ & $867(31.2)$ & \\
\hline 3-vessel disease & $394(34.5)$ & $1078(38.7)$ & \\
\hline CTO artery, $n$ (\%): & & & $<0.001$ \\
\hline RCA & $538(46.2)$ & $1747(61.7)$ & \\
\hline LAD & $349(30.0)$ & $629(22.2)$ & \\
\hline$C x$ & $263(22.6)$ & $421(14.9)$ & \\
\hline$L M$ & $12(1.0)$ & $18(0.6)$ & \\
\hline СТO in bypass & $2(0.2)$ & $16(0.6)$ & \\
\hline СTO in side branch & $59(5.1)$ & $51(1.8)$ & $<0.001$ \\
\hline Ostial CTO & $110(9.4)$ & $389(13.8)$ & $<0.001$ \\
\hline Occlusion duration, $n(\%)$ : & & & $<0.001$ \\
\hline $3-6$ months & $514(44.0)$ & $890(31.4)$ & \\
\hline $7-12$ months & $277(23.7)$ & $687(24.3)$ & \\
\hline Over 12 months & $376(32.2)$ & $1255(44.3)$ & \\
\hline
\end{tabular}


Table IV. Cont.

\begin{tabular}{|c|c|c|c|}
\hline Parameter & $\begin{array}{c}\text { Procedure success - } \\
\text { not successful }(n=494)\end{array}$ & $\begin{array}{l}\text { Procedure success - successful } \\
\qquad(n=3550)\end{array}$ & $P$-value \\
\hline Age [years] & $66.0(60.0-73.0)$ & $64.0(57.0-72.0)$ & $<0.001$ \\
\hline Gender (male), $n(\%)$ & $423(85.8)$ & $3026(85.3)$ & 0.804 \\
\hline BMI $\left[\mathrm{kg} / \mathrm{m}^{2}\right]$ & $28.4(26.0-31.6)$ & $27.9(25.4-31.1)$ & 0.014 \\
\hline Hypertension, $n(\%)$ & $410(83.0)$ & $2843(80.1)$ & 0.142 \\
\hline Hypercholesterolemia, $n(\%)$ & $386(78.1)$ & $2830(79.7)$ & 0.45 \\
\hline Diabetes, $n(\%)$ & $181(39.4)$ & $1072(32.4)$ & 0.003 \\
\hline Smoker, $n(\%)$ & $92(20.0)$ & $761(23.0)$ & 0.179 \\
\hline PAD, $n(\%)$ & $80(16.2)$ & $348(9.8)$ & $<0.001$ \\
\hline COPD, $n(\%)$ & $40(8.1)$ & $156(4.4)$ & 0.001 \\
\hline Prior stroke, $n(\%)$ & $22(4.5)$ & $88(2.5)$ & 0.017 \\
\hline Previous MI, $n(\%)$ & $234(49.0)$ & $1535(44.3)$ & 0.059 \\
\hline Previous CABG, $n(\%)$ & $115(23.3)$ & $583(16.4)$ & $<0.001$ \\
\hline Previous PCI, $n(\%)$ & $299(60.5)$ & $1777(50.1)$ & $<0.001$ \\
\hline GFR $\left[\mathrm{ml} / \mathrm{min} / 1.73 \mathrm{~m}^{2}\right]$ & $84.7(66.4-106.9)$ & $89.1(69.4-111.0)$ & 0.016 \\
\hline Left ventricular $\mathrm{EF}<35 \%, n(\%)$ & $34(7.0)$ & $213(6.0)$ & 0.488 \\
\hline Number of diseased vessels, $n(\%)$ : & & & 0.213 \\
\hline 1 -vessel disease & $136(28.2)$ & $1086(31.2)$ & \\
\hline 2-vessel disease & $148(30.7)$ & $1106(31.7)$ & \\
\hline 3-vessel disease & $198(41.1)$ & $1294(37.1)$ & \\
\hline CTO artery, $n(\%):$ & & & 0.02 \\
\hline RCA & $316(64.0)$ & $2000(56.4)$ & \\
\hline LAD & $102(20.6)$ & $883(24.9)$ & \\
\hline$C x$ & $74(15.0)$ & $617(17.4)$ & \\
\hline LM & $1(0.2)$ & $29(0.8)$ & \\
\hline CTO in bypass & $1(0.2)$ & $17(0.5)$ & \\
\hline CTO in side branch & $10(2.0)$ & $102(2.9)$ & 0.35 \\
\hline Ostial CTO & $97(19.7)$ & $413(11.7)$ & $<0.001$ \\
\hline In stent CTO & $31(6.3)$ & $367(10.3)$ & 0.006 \\
\hline Bifurcation, $n(\%)$ & $130(26.3)$ & $992(27.9)$ & 0.482 \\
\hline Vessel diameter [mm] & $3.0(2.8-3.0)$ & $3.0(2.5-3.0)$ & 0.839 \\
\hline CTO length [mm] & $30.0(20.0-40.0)$ & $25.0(15.0-35.0)$ & $<0.001$ \\
\hline Collateral circulation type 2, $n$ (\%) & $118(25.1)$ & $963(28.5)$ & 0.135 \\
\hline Proximal tortuosity, $n(\%)$ & $134(27.7)$ & $631(18.1)$ & $<0.001$ \\
\hline In CTO bend, $n(\%)$ & $254(52.4)$ & $1078(30.5)$ & $<0.001$ \\
\hline Moderate and severe calcification, $n(\%)$ & $307(62.8)$ & $1400(39.6)$ & $<0.001$ \\
\hline Blunt stump, $n(\%)$ & $243(49.4)$ & $1506(42.6)$ & 0.005 \\
\hline Side branch 3 mm proximal to CTO, $n$ (\%) & $133(26.9)$ & $943(26.6)$ & 0.908 \\
\hline Visible distal opacification, $n(\%)$ & $143(29.2)$ & $1652(46.7)$ & $<0.001$ \\
\hline Severe distal disease, $n(\%)$ & $251(53.0)$ & $1360(39.6)$ & $<0.001$ \\
\hline One or more previous attempts, $n(\%)$ & $185(37.4)$ & $1167(32.9)$ & 0.049 \\
\hline Retrograde approach, $n(\%)$ & $207(41.9)$ & $1010(28.5)$ & $<0.001$ \\
\hline $\mathrm{AE}, n(\%)$ & $24(4.9)$ & $89(2.5)$ & 0.005 \\
\hline Occlusion duration, $n(\%)$ : & & & $<0.001$ \\
\hline $3-6$ months & $112(22.7)$ & $1303(36.7)$ & \\
\hline $7-12$ months & $109(22.1)$ & $864(24.3)$ & \\
\hline Over 12 months & $273(55.3)$ & $1383(39.0)$ & \\
\hline Parameter & $\begin{array}{c}\text { Non-AE } \\
(n=3931)\end{array}$ & $\begin{array}{c}\mathrm{AE} \\
(n=113)\end{array}$ & $P$-value \\
\hline Age [years] & $64.0(57.0-72.0)$ & $66.0(59.0-73.0)$ & 0.056 \\
\hline Gender (male), n (\%) & $3363(85.6)$ & $86(76.1)$ & 0.007 \\
\hline
\end{tabular}


Table IV. Cont.

\begin{tabular}{|c|c|c|c|}
\hline Parameter & $\begin{array}{c}\text { Non-AE } \\
(n=3931)\end{array}$ & $\begin{array}{c}\mathrm{AE} \\
(n=113)\end{array}$ & $P$-value \\
\hline BMI [kg/m²] & $28.0(25.5-31.1)$ & $27.7(24.8-31.1)$ & 0.275 \\
\hline Hypertension, $n(\%)$ & $3154(80.2)$ & 99 (87.6) & 0.067 \\
\hline Hypercholesterolemia, $n$ (\%) & $3119(79.3)$ & $97(85.8)$ & 0.117 \\
\hline Diabetes, $n(\%)$ & $1220(33.3)$ & $33(31.7)$ & 0.825 \\
\hline Smoker, $n(\%)$ & $834(22.7)$ & $19(18.3)$ & 0.339 \\
\hline PAD, $n(\%)$ & $407(10.4)$ & $21(18.6)$ & 0.008 \\
\hline COPD, $n(\%)$ & $186(4.7)$ & $10(8.8)$ & 0.074 \\
\hline Prior stroke, $n(\%)$ & $103(2.6)$ & $7(6.2)$ & 0.033 \\
\hline Previous MI, $n(\%)$ & $1709(44.6)$ & $60(53.6)$ & 0.073 \\
\hline Previous CABG, $n(\%)$ & $674(17.2)$ & $24(21.2)$ & 0.314 \\
\hline Previous PCI, $n(\%)$ & $2017(51.3)$ & $59(52.2)$ & 0.927 \\
\hline GFR $\left[\mathrm{ml} / \mathrm{min} / 1.73 \mathrm{~m}^{2}\right]$ & $89.0(69.0-110.8)$ & $81.2(67.3-101.7)$ & 0.013 \\
\hline Left ventricular EF <35\%, $n(\%)$ & $235(6.0)$ & $12(10.6)$ & 0.07 \\
\hline Number of diseased vessels, $n$ (\%): & & & 0.683 \\
\hline 1 -vessel disease & $1192(30.9)$ & $30(27.0)$ & \\
\hline 2-vessel disease & $1217(31.6)$ & $37(33.3)$ & \\
\hline 3-vessel disease & $1448(37.5)$ & $44(39.6)$ & \\
\hline CTO artery, $\mathrm{n}(\%)$ : & & & 0.707 \\
\hline RCA & $2254(57.4)$ & $62(54.9)$ & \\
\hline$\underline{L A D}$ & $956(24.3)$ & $29(25.7)$ & \\
\hline$C x$ & $670(17.1)$ & $21(18.6)$ & \\
\hline$L M$ & $30(0.8)$ & $0(0.0)$ & \\
\hline CTO in bypass & $17(0.4)$ & $1(0.9)$ & \\
\hline CTO in side branch & $108(2.8)$ & $4(3.5)$ & 0.555 \\
\hline Ostial CTO, $n(\%)$ & $494(12.6)$ & $16(14.2)$ & 0.728 \\
\hline In stent CTO, $n(\%)$ & $391(9.9)$ & $7(6.2)$ & 0.246 \\
\hline Bifurcation, $n(\%)$ & $1085(27.6)$ & $37(32.7)$ & 0.273 \\
\hline Vessel diameter [mm] & $3.0(2.5-3.0)$ & $3.0(2.5-3.0)$ & 0.805 \\
\hline CTO length [mm] & $25.0(15.0-35.0)$ & $30.0(18.0-40.0)$ & 0.136 \\
\hline Collateral circulation type $2, n(\%)$ & $1043(27.9)$ & $38(33.9)$ & 0.195 \\
\hline Proximal tortuosity, $n(\%)$ & $750(19.5)$ & $15(13.4)$ & 0.138 \\
\hline In CTO bend, $n(\%)$ & $1285(32.9)$ & $47(41.6)$ & 0.067 \\
\hline Moderate and severe calcification, $n(\%)$ & $1658(42.4)$ & $49(43.4)$ & 0.908 \\
\hline Blunt stump, $n(\%)$ & $1702(43.5)$ & $47(41.6)$ & 0.765 \\
\hline Side branch $3 \mathrm{~mm}$ proximal to CTO, $n$ (\%) & $1041(26.5)$ & $35(31.0)$ & 0.338 \\
\hline Visible distal opacification, $n(\%)$ & $1743(44.6)$ & $52(46.0)$ & 0.834 \\
\hline Severe distal disease, $n(\%)$ & $1567(41.3)$ & $44(38.9)$ & 0.69 \\
\hline One or more previous attempts, $n(\%)$ & $1315(33.5)$ & $37(32.7)$ & 0.955 \\
\hline Retrograde approach, $n(\%)$ & $1165(29.6)$ & $52(46.0)$ & $<0.001$ \\
\hline Procedural failure, $n(\%)$ & $470(12.0)$ & $24(21.2)$ & 0.005 \\
\hline Occlusion duration, $n$ (\%): & & & 0.024 \\
\hline $3-6$ months & $1386(35.3)$ & $29(25.7)$ & \\
\hline $7-12$ months & $949(24.1)$ & $24(21.2)$ & \\
\hline Over 12 months & $1596(40.6)$ & $60(53.1)$ & \\
\hline
\end{tabular}

Values are median $\left(25^{\text {th }}-75^{\text {th }}\right.$ percentile) or $n$ (\%). AE - adverse events, BMI-body mass index, CABG - coronary artery bypass grafting, COPD - chronic obstructive pulmonary disease, CTO - chronic total occlusion, CX-circumflex artery, EF-ejection fraction, GFR-glomerular filtration rate, LAD - left anterior descending artery, $L M$ - left main artery, $M I-$ myocardial infarction, $P A D$ - peripheral artery disease, $P C I$ - percutaneous coronary intervention, $R C A$ - right coronary artery. For calcification, lesion length and collateral circulation only clinical predictors were included in the analysis. For procedural success and AE clinical, lesion characteristics and retrograde approach were included in the analysis. 
Table V. Predictors for lesion characteristics and adverse events - multivariate analysis

\begin{tabular}{|c|c|c|c|c|}
\hline Variable & OR & $\begin{array}{c}95 \% \mathrm{Cl} \\
\text { lower bound }\end{array}$ & $\begin{array}{c}95 \% \mathrm{Cl} \\
\text { upper bound }\end{array}$ & $P$-value \\
\hline \multicolumn{5}{|l|}{ Calcification (moderate or severe): } \\
\hline Occlusion duration 7-12 months & 1.14 & 0.95 & 1.38 & 0.165 \\
\hline Occlusion duration $>12$ months & 1.52 & 1.28 & 1.8 & $<0.001$ \\
\hline \multicolumn{5}{|l|}{ Collateral circulation type 2: } \\
\hline Occlusion duration 7-12 months & 1.26 & 1.03 & 1.53 & 0.021 \\
\hline Occlusion duration $>12$ months & 1.2 & 1.01 & 1.43 & 0.041 \\
\hline \multicolumn{5}{|l|}{ Lesion length $20 \mathrm{~mm}$ : } \\
\hline Occlusion duration 7-12 months & 1.43 & 1.19 & 1.72 & $<0.001$ \\
\hline Occlusion duration > 12 months & 1.77 & 1.49 & 2.1 & $<0.001$ \\
\hline \multicolumn{5}{|l|}{ Procedural success: } \\
\hline Occlusion duration 7-12 months & 0.78 & 0.57 & 1.06 & 0.116 \\
\hline Occlusion duration > 12 months & 0.6 & 0.46 & 0.79 & $<0.001$ \\
\hline \multicolumn{5}{|l|}{ AE: } \\
\hline Occlusion duration 7-12 months & 1.17 & 0.67 & 2.03 & 0.578 \\
\hline Occlusion duration > 12 months & 1.56 & 0.98 & 2.47 & 0.06 \\
\hline
\end{tabular}

Only results for occlusion duration (as compared to occlusion duration 3-6 months) are presented in the table. Full multivariate analysis is presented in Table VI. $A E$-adverse events, $\mathrm{Cl}$-confidence interval, CTO - chronic total occlusion, OR - odds ratio. Number of patients included in the analysis (n): calcification (moderate or severe), $n=3589$; collateral circulation type 2, $n=3739$; Lesion length $20 \mathrm{~mm}, n=3815 ; A E, n=4037$.

during the hospitalization period. A recent study showed that complications during $\mathrm{PCl}$ of CTO were more frequent in females [28]. In concordance with that observation, female gender was one of two AE predictors in our study. Not surprisingly, the retrograde approach was the other predictor of AEs as this approach is considered as more complex when compared to the antegrade approach $[6,29]$. However, it should be noted that the retrograde approach is often used in very advanced lesions where the antegrade approach is not feasible or ended with failure. Importantly, although patients with the longest CTO duration had higher incidence of $\mathrm{AES}$ as compared to the patients with the shortest CTO duration, the age of the CTO was not an independent predictor of AEs. Barlis et al. in their study compared AEs in patients with undetermined and known occlusion duration [30]. In long-term follow-up they found that undetermined occlusion duration was a predictor of AEs. In contrast to our study they did not find any differences in in-hospital outcomes between groups with known and unknown occlusion duration. However, their study was limited by the sample size.

\section{Limitations}

First, our study is limited by its observational design. Second, angiography-dependent and clinical outcomes were not independently adjudicated. Third, data regard- ing patients and lesion and procedural characteristics were missing in some cases. Moreover, only in half of the patients could CTO age be assessed. Out of 10699 patients, 4044 (37.8\%) were included in the final analysis, which could have involved selection bias. Further, patients excluded from the study differed from those included in important lesion characteristics such as lesion location, number of previous attempts and severity of coronary artery disease. Lastly, the exact age of the CTO is often unclear. Hence, it is often very challenging to determine the exact age of the CTO.

\section{Conclusions}

Longer CTO duration is associated with greater prevalence of calcification, longer lesions, and better developed collateral circulation. Most importantly, in our study longer CTO duration was associated with lower revascularization success by $\mathrm{PCl}$. However, it did not affect the rate of in-hospital AEs. Our results should be taken into account when planning procedures of CTO older than 12 months.

\section{Conflict of interest}

The authors declare no conflict of interest. 
Table VI. Full multivariate analysis

\begin{tabular}{|c|c|c|c|c|}
\hline Parameter & OR & 95\% Cl lower bound & $95 \% \mathrm{Cl}$ upper bound & $P$-value \\
\hline \multicolumn{5}{|l|}{ Calcification (moderate or severe): } \\
\hline Age & 1.03 & 1.02 & 1.04 & $<0.001$ \\
\hline Gender (male) & 1.31 & 1.06 & 1.61 & 0.011 \\
\hline $\mathrm{BMI}$ & 1.02 & 1 & 1.03 & 0.038 \\
\hline Occlusion duration $7-12$ months $^{1}$ & 1.14 & 0.95 & 1.38 & 0.165 \\
\hline Occlusion duration over 12 months $^{1}$ & 1.52 & 1.28 & 1.8 & $<0.001$ \\
\hline Hypertension & 1.13 & 0.94 & 1.37 & 0.201 \\
\hline Hypercholesterolemia & 1.21 & 1.01 & 1.45 & 0.038 \\
\hline Diabetes & 1.21 & 1.03 & 1.41 & 0.017 \\
\hline Smoker & 0.86 & 0.72 & 1.03 & 0.107 \\
\hline PAD & 1.4 & 1.11 & 1.76 & 0.005 \\
\hline COPD & 1.64 & 1.19 & 2.27 & 0.003 \\
\hline Previous CABG & 1.58 & 1.28 & 1.96 & $<0.001$ \\
\hline Previous $\mathrm{PCl}$ & 1.14 & 0.98 & 1.31 & 0.084 \\
\hline CKD class 4 & 2.45 & 1.4 & 4.31 & 0.002 \\
\hline 2-vessel CAD disease & 1.46 & 1.21 & 1.75 & $<0.001$ \\
\hline 3- vessel CAD disease & 1.82 & 1.51 & 2.2 & $<0.001$ \\
\hline CTO in bypass ${ }^{2}$ & 0.02 & 0 & 0.16 & $<0.001$ \\
\hline CTO in $L A D^{2}$ & 0.85 & 0.72 & 1.01 & 0.068 \\
\hline CTO in Cx & 0.51 & 0.41 & 0.63 & $<0.001$ \\
\hline CTO in $\mathrm{LM}^{2}$ & 5.31 & 1.21 & 23.17 & 0.027 \\
\hline CTO in side branch & 0.41 & 0.26 & 0.66 & $<0.001$ \\
\hline Ostial CTO & 2.07 & 1.66 & 2.6 & $<0.001$ \\
\hline \multicolumn{5}{|l|}{ Collateral circulation 2: } \\
\hline Age & 1 & 1 & 1.01 & 0.472 \\
\hline Gender (male) & 1.47 & 1.18 & 1.83 & 0.001 \\
\hline BMI & 0.99 & 0.98 & 1.01 & 0.394 \\
\hline Occlusion duration $7-12$ months $^{1}$ & 1.26 & 1.03 & 1.53 & 0.021 \\
\hline Occlusion duration over 12 months $^{1}$ & 1.2 & 1.01 & 1.43 & 0.041 \\
\hline Previous CABG & 1.46 & 1.17 & 1.82 & 0.001 \\
\hline Left ventricular EF <35\% & 0.67 & 0.48 & 0.94 & 0.022 \\
\hline 2-vessel CAD disease & 0.79 & 0.66 & 0.94 & 0.01 \\
\hline 3-vessel CAD disease & 0.66 & 0.54 & 0.8 & $<0.001$ \\
\hline CTO in bypass ${ }^{2}$ & 0.14 & 0.02 & 1.08 & 0.059 \\
\hline CTO in $L A D^{2}$ & 0.88 & 0.74 & 1.05 & 0.154 \\
\hline $\mathrm{CTO}$ in $\mathrm{Cx}^{2}$ & 0.57 & 0.46 & 0.72 & $<0.001$ \\
\hline CTO in $\mathrm{LM}^{2}$ & 1.45 & 0.65 & 3.23 & 0.362 \\
\hline CTO in side branch & 0.31 & 0.16 & 0.6 & 0.001 \\
\hline Ostial CTO & 1.49 & 1.2 & 1.85 & $<0.001$ \\
\hline \multicolumn{5}{|l|}{ Lesion length > $20 \mathrm{~mm}$ : } \\
\hline Age & 0.99 & 0.98 & 1 & 0.019 \\
\hline Gender (male) & 1.19 & 0.97 & 1.45 & 0.087 \\
\hline BMI & 1.02 & 1 & 1.03 & 0.05 \\
\hline 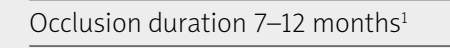 & 1.43 & 1.19 & 1.72 & $<0.001$ \\
\hline Occlusion duration over 12 months $^{1}$ & 1.77 & 1.49 & 2.1 & $<0.001$ \\
\hline PAD & 1.27 & 0.99 & 1.64 & 0.059 \\
\hline Previous MI & 1.12 & 0.96 & 1.3 & 0.146 \\
\hline Previous CABG & 1.17 & 0.93 & 1.48 & 0.183 \\
\hline
\end{tabular}


Table VI. Cont.

\begin{tabular}{|c|c|c|c|c|}
\hline Parameter & OR & $95 \% \mathrm{Cl}$ lower bound & $95 \% \mathrm{Cl}$ upper bound & $P$-value \\
\hline Previous PCl & 1.19 & 1.03 & 1.38 & 0.022 \\
\hline 2-vessel CAD disease & 1.03 & 0.86 & 1.23 & 0.749 \\
\hline 3-vessel CAD disease & 1.17 & 0.96 & 1.42 & 0.112 \\
\hline CTO in bypass ${ }^{2}$ & 1.71 & 0.38 & 7.79 & 0.488 \\
\hline CTO in $L A D^{2}$ & 0.6 & 0.51 & 0.71 & $<0.001$ \\
\hline $\mathrm{CTO}$ in $C x^{2}$ & 0.52 & 0.43 & 0.64 & $<0.001$ \\
\hline $\mathrm{CTO}$ in $\mathrm{LM}^{2}$ & 0.27 & 0.12 & 0.61 & 0.002 \\
\hline CTO in side branch & 0.32 & 0.21 & 0.48 & $<0.001$ \\
\hline Ostial CTO & 1.85 & 1.44 & 2.37 & $<0.001$ \\
\hline \multicolumn{5}{|l|}{ Procedural success: } \\
\hline Age & 0.99 & 0.97 & 1 & 0.015 \\
\hline Gender (male) & 1 & 0.73 & 1.37 & 0.997 \\
\hline $\mathrm{BMI}$ & 0.98 & 0.96 & 1.01 & 0.132 \\
\hline Occlusion duration 7-12 months ${ }^{1}$ & 0.78 & 0.57 & 1.06 & 0.116 \\
\hline Occlusion duration over 12 months $^{1}$ & 0.6 & 0.46 & 0.79 & $<0.001$ \\
\hline Diabetes & 0.89 & 0.71 & 1.12 & 0.314 \\
\hline PAD & 0.7 & 0.51 & 0.95 & 0.024 \\
\hline COPD & 0.61 & 0.4 & 0.93 & 0.022 \\
\hline Prior stroke & 0.65 & 0.37 & 1.12 & 0.122 \\
\hline Previous CABG & 1.01 & 0.76 & 1.34 & 0.956 \\
\hline Previous PCl & 0.61 & 0.49 & 0.77 & $<0.001$ \\
\hline CTO in bypass ${ }^{2}$ & 2.99 & 0.37 & 24.24 & 0.305 \\
\hline CTO in $L A D^{2}$ & 0.99 & 0.75 & 1.3 & 0.917 \\
\hline $\mathrm{CTO}$ in $C x^{2}$ & 1.27 & 0.92 & 1.76 & 0.148 \\
\hline $\mathrm{CTO}$ in $\mathrm{LM}^{2}$ & 6.48 & 0.83 & 50.51 & 0.075 \\
\hline Ostial CTO & 0.58 & 0.43 & 0.78 & $<0.001$ \\
\hline In stent CTO & 1.9 & 1.23 & 2.93 & 0.004 \\
\hline Lesion length > $20 \mathrm{~mm}$ & 0.61 & 0.46 & 0.83 & 0.001 \\
\hline Proximal tortuosity & 0.85 & 0.66 & 1.11 & 0.239 \\
\hline In CTO bend & 0.57 & 0.46 & 0.71 & $<0.001$ \\
\hline Moderate/severe calcification & 0.55 & 0.43 & 0.7 & $<0.001$ \\
\hline Blunt stump & 0.79 & 0.63 & 0.98 & 0.034 \\
\hline Visible distal opacification & 1.77 & 1.39 & 2.24 & $<0.001$ \\
\hline Severe distal disease & 0.99 & 0.79 & 1.26 & 0.965 \\
\hline One or more previous attempts & 0.87 & 0.69 & 1.09 & 0.231 \\
\hline \multicolumn{5}{|l|}{ AE: } \\
\hline Age & 1.01 & 0.99 & 1.03 & 0.313 \\
\hline Gender (male) & 0.52 & 0.33 & 0.81 & 0.004 \\
\hline $\mathrm{BMI}$ & 0.98 & 0.94 & 1.03 & 0.44 \\
\hline Occlusion duration 7-12 months ${ }^{1}$ & 1.17 & 0.67 & 2.03 & 0.578 \\
\hline Occlusion duration over 12 months $^{1}$ & 1.56 & 0.98 & 2.47 & 0.06 \\
\hline PAD & 1.67 & 1.02 & 2.76 & 0.043 \\
\hline Prior stroke & 2.09 & 0.93 & 4.73 & 0.075 \\
\hline Retrograde approach & 1.93 & 1.31 & 2.83 & 0.001 \\
\hline
\end{tabular}

$A E$ - adverse events, $B M I$ - body mass index, $C A B G$ - coronary artery bypass grafting, CAD - coronary artery disease, CI-confidence interval, CKD - chronic kidney disease, COPD - chronic obstructive pulmonary disease, CTO - chronic total occlusion, CX - circumflex artery, EF - ejection fraction, LAD - left anterior descending artery, $L M$ - left main artery, $O R$ - odds ratio, PAD - peripheral artery disease, $P C I$ - percutaneous coronary intervention. ${ }^{1} A s$ compared to occlusion duration 3-6 months; ${ }^{2}$ as compared to right coronary artery. For calcification, lesion length and collateral circulation only clinical predictors were included in the analysis. For procedural success and AE clinical, lesion characteristics and retrograde approach were included in the analysis. Number of patients included in the analysis (n): calcification (moderate or severe), $n=3589$; collateral circulation type 2, $n=3739$; lesion length $20 \mathrm{~mm}, n=3815 ;$ procedural success, $n=3513 ;$ AE, $n=4037$. 
Table VII. Comparison between patients with undetermined age of the occlusion and known occlusion duration

\begin{tabular}{|c|c|c|c|}
\hline Parameter & $\begin{array}{l}\text { Undetermined age of the } \\
\text { occlusion }(n=5033)\end{array}$ & $\begin{array}{l}\text { Known occlusion duration } \\
\qquad(n=4044)\end{array}$ & $P$-value \\
\hline Age [years] & $64.0(57.0-72.0)$ & $64.0(57.0-72.0)$ & 0.862 \\
\hline Gender (male), $n$ (\%) & $4246(84.4)$ & 3449 (85.3) & 0.239 \\
\hline BMI $\left[\mathrm{kg} / \mathrm{m}^{2}\right]$ & $27.7(25.1-30.7)$ & $28.0(25.4-31.1)$ & $<0.001$ \\
\hline Hypertension, $n(\%)$ & $3824(76.0)$ & $3253(80.4)$ & $<0.001$ \\
\hline Hypercholesterolemia, $n$ (\%) & $3548(70.5)$ & 3216 (79.5) & $<0.001$ \\
\hline Diabetes, $n(\%)$ & $1546(32.9)$ & $1253(33.2)$ & 0.78 \\
\hline Smoker, $n(\%)$ & $1367(29.1)$ & $853(22.6)$ & $<0.001$ \\
\hline $\mathrm{PAD}, n(\%)$ & $594(11.8)$ & $428(10.6)$ & 0.073 \\
\hline COPD, $n(\%)$ & $262(5.2)$ & $196(4.8)$ & 0.466 \\
\hline Prior stroke, $n(\%)$ & $147(2.9)$ & $110(2.7)$ & 0.611 \\
\hline Previous MI, $n(\%)$ & $1807(37.5)$ & $1769(44.8)$ & $<0.001$ \\
\hline Previous CABG, $n(\%)$ & $406(8.1)$ & $698(17.3)$ & $<0.001$ \\
\hline Previous PCI, $n(\%)$ & $2492(49.5)$ & $2076(51.3)$ & 0.086 \\
\hline GFR $\left[\mathrm{ml} / \mathrm{min} / 1.73 \mathrm{~m}^{2}\right]$ & $86.9(67.0-109.4)$ & $88.6(68.9-110.7)$ & 0.006 \\
\hline Left ventricular $\mathrm{EF}<35 \%, n(\%)$ & $412(8.2)$ & $247(6.1)$ & $<0.001$ \\
\hline Number of diseased vessels, $n(\%)$ : & & & $<0.001$ \\
\hline 1-vessel disease & $1677(34.4)$ & $1222(30.8)$ & \\
\hline 2-vessel disease & $1654(33.9)$ & 1254 (31.6) & \\
\hline 3-vessel disease & 1549 (31.7) & $1492(37.6)$ & \\
\hline CTO artery, $n(\%)$ : & & & $<0.001$ \\
\hline RCA & $2746(54.7)$ & $2316(57.3)$ & \\
\hline$\underline{L A D}$ & $1338(26.6)$ & $985(24.4)$ & \\
\hline$C x$ & $914(18.2)$ & $691(17.1)$ & \\
\hline LM & $13(0.3)$ & $30(0.7)$ & \\
\hline СTO in bypass & $12(0.2)$ & $18(0.4)$ & \\
\hline CTO in side branch & $110(2.2)$ & $112(2.8)$ & 0.086 \\
\hline Ostial CTO & $463(9.2)$ & $510(12.6)$ & $<0.001$ \\
\hline In-stent CTO & $369(7.3)$ & $398(9.8)$ & $<0.001$ \\
\hline Bifurcation & $1275(25.3)$ & $1122(27.7)$ & 0.01 \\
\hline Vessel diameter [mm] & $3.0(2.5-3.0)$ & $3.0(2.5-3.0)$ & 0.136 \\
\hline CTO length $[\mathrm{mm}]$ & $25.0(15.0-35.0)$ & $25.0(15.0-35.0)$ & 0.225 \\
\hline Collateral circulation type $2, n(\%)$ & $1443(31.5)$ & $1081(28.1)$ & 0.001 \\
\hline Proximal tortuosity, $n(\%)$ & $941(19.0)$ & $765(19.3)$ & 0.714 \\
\hline In CTO bend, $n(\%)$ & $1550(31.0)$ & $1332(33.2)$ & 0.034 \\
\hline Moderate and severe calcification, $n(\%)$ & $2182(43.5)$ & $1707(42.4)$ & 0.294 \\
\hline Blunt stump, $n(\%)$ & $2043(40.7)$ & $1749(43.4)$ & 0.01 \\
\hline Visible distal opacification, $n(\%)$ & $2043(41.0)$ & $1795(44.6)$ & 0.001 \\
\hline Severe distal disease, $n(\%)$ & $1721(38.5)$ & $1611(41.2)$ & 0.013 \\
\hline One or more previous attempts, $n(\%)$ & $1115(22.2)$ & $1352(33.4)$ & $<0.001$ \\
\hline Retrograde approach, $n(\%)$ & $1411(28.0)$ & $1217(30.1)$ & 0.033 \\
\hline Procedural failure, $n(\%)$ & $597(11.9)$ & $494(12.2)$ & 0.629 \\
\hline $\mathrm{AE}, n(\%)$ & $185(3.7)$ & $113(2.8)$ & 0.019 \\
\hline Radial access, $n(\%)$ & $2324(46.2)$ & 1290 (31.9) & $<0.001$ \\
\hline Rotablation, $n(\%)$ & $122(12.4)$ & $100(2.5)$ & 0.881 \\
\hline IVUS, $n(\%)$ & $653(13.0)$ & $503(12.4)$ & 0.446 \\
\hline Procedure time & $90.0(60.0-129.0)$ & $100.0(63.0-144.0)$ & $<0.001$ \\
\hline Fluoroscopy time & $33.0(19.0-55.0)$ & $37.0(22.0-60.8)$ & $<0.001$ \\
\hline Dye used & $236.0(170.0-320.0)$ & $250.0(180.0-350.0)$ & $<0.001$ \\
\hline
\end{tabular}

Values are median ( $25^{\text {th }}-75^{\text {th }}$ percentile) or $n(\%)$. AE - adverse events, $B M I$ - body mass index, CABG - coronary artery bypass grafting, COPD - chronic obstructive pulmonary disease, CTO - chronic total occlusion, CX-circumflex artery, EF- ejection fraction, GFR-glomerular filtration rate, LAD-left anterior descending artery, $L M$ - left main artery, $\mathrm{MI}$ - myocardial infarction, $P A D$ - peripheral artery disease, $P C I$ - percutaneous coronary intervention, $R C A$ - right coronary artery. Out of 5933 patients with undetermined age of the occlusion, 900 were excluded due to insufficient data regarding the occlusion characteristics. In the end a total of 4044 patients with known occlusion duration and 5033 patients with undetermined age of the occlusion were included in the data analysis. 


\section{References}

1. Råmunddal T, Hoebers L, Henriques JPS, et al. Chronic total occlusions in sweden - a report from the Swedish Coronary Angiography and Angioplasty Registry (SCAAR). PLoS One 2014; 9: e103850.

2. Patel VG, Brayton KM, Tamayo A, et al. Angiographic success and procedural complications in patients undergoing percutaneous coronary chronic total occlusion interventions: a weighted meta-analysis of 18,061 patients from 65 studies. JACC Cardiovasc Interv 2013; 6: 128-36.

3. Fefer P, Knudtson ML, Cheema AN, et al. Current perspectives on coronary chronic total occlusions: the Canadian Multicenter Chronic Total Occlusions Registry. J Am Coll Cardiol 2012; 59: 991-7.

4. Wolff R, Fefer P, Knudtson ML, et al. Gender differences in the prevalence and treatment of coronary chronic total occlusions. Catheter Cardiovasc Interv 2016; 87: 1063-70.

5. Galassi AR, Boukhris M, Azzarelli S, et al. Percutaneous coronary revascularization for chronic total occlusions: a novel predictive score of technical failure using advanced technologies. JACC Cardiovasc Interv 2016; 9: 911-22.

6. Galassi AR, Sianos G, Werner GS, et al. Retrograde recanalization of chronic total occlusions in Europe: procedural, in-hospital, and long-term outcomes from the multicenter ERCTO registry. J Am Coll Cardiol 2015; 65: 2388-400.

7. Ellis SG, Burke MN, Murad MB, et al. Predictors of successful hybrid-approach chronic total coronary artery occlusion stenting: an improved model with novel correlates. JACC Cardiovasc Interv 2017; 10: 1089-98.

8. Råmunddal T, Hoebers LP, Henriques JPS, et al. Prognostic impact of chronic total occlusions: a report from SCAAR (Swedish Coronary Angiography and Angioplasty Registry). JACC CardiovasC Interv 2016; 9: 1535-44.

9. Wyman RM. Do we need another predictive scoring tool for chronic total occlusion percutaneous coronary intervention? JACC Cardiovasc Interv 2015; 8: 1549-51.

10. Danek BA, Karatasakis A, Karmpaliotis D, et al. Effect of lesion age on outcomes of chronic total occlusion percutaneous coronary intervention: insights from a contemporary US multicenter registry. Canad J Cardiol 2016; 32:1433-9.

11. Tomasello SD, Costanzo L, Campisano MB, et al. Does occlusion duration influence procedural and clinical outcome of patients who underwent percutaneous coronary intervention for chronic total occlusion? J Interv Cardiol 2011; 24: 223-31.

12. Choi JH, Kim EK, Kim SM, et al. Noninvasive discrimination of coronary chronic total occlusion and subtotal occlusion by coronary computed tomography angiography. JACC Cardiovasc Interv 2015; 8: 1143-53.

13. Cho JR, Kim YJ, Ahn CM, et al. Quantification of regional calcium burden in chronic total occlusion by 64-slice multi-detector computed tomography and procedural outcomes of percutaneous coronary intervention. Int J Cardiol 2010; 145: 9-14.

14. Opolski MP, Achenbach S, Schuhbäck A, et al. Coronary computed tomographic prediction rule for time-efficient guidewire crossing through chronic total occlusion: insights from the CT-RECTOR multicenter registry (Computed Tomography Registry of Chronic Total Occlusion Revascularization). JACC Cardiovasc Interv 2015; 8: 257-67.

15. Werner GS, Ferrari M, Heinke S, et al. Angiographic assessment of collateral connections in comparison with invasively deter- mined collateral function in chronic coronary occlusions. Circulation 2003; 107: 1972-7.

16. Sianos G, Werner GS, Galassi AR, et al. Recanalisation of chronic total coronary occlusions: 2012 consensus document from the EuroCTO club. EuroIntervention 2012; 8: 139-45.

17. Morino Y, Abe M, Morimoto T, et al. Predicting successful guidewire crossing through chronic total occlusion of native coronary lesions within 30 minutes: the J-CTO (Multicenter CTO Registry in Japan) score as a difficulty grading and time assessment tool. JACC Cardiovasc Interv 2011; 4: 213-21.

18. Alessandrino G, Chevalier B, Lefèvre T, et al. A Clinical and Angiographic scoring system to predict the probability of successful first-attempt percutaneous coronary intervention in patients with total chronic coronary occlusion. JACC Cardiovasc Interv 2015; 8: 1540-8.

19. Doherty TM, Detrano RC. Coronary arterial calcification as an active process: a new perspective on an old problem. Calcif Tissue Int 1994; 54: 224-30.

20. Srivatsa SS, Edwards WD, Boos CM, et al. Histologic correlates of angiographic chronic total coronary artery occlusions: influence of occlusion duration on neovascular channel patterns and intimal plaque composition. J Am Coll Cardiol 1997; 29: 955-63.

21. Sakakura K, Nakano M, Otsuka F, et al. Comparison of pathology of chronic total occlusion with and without coronary artery bypass graft. Eur Heart J 2014; 35: 1683-93.

22. Werner GS. The role of coronary collaterals in chronic total occlusions. Curr Cardiol Rev 2014; 10: 57-64.

23. Christopoulos G, Kandzari DE, Yeh RW, et al. Development and validation of a novel scoring system for predicting technical success of chronic total occlusion percutaneous coronary interventions: the PROGRESS CTO (Prospective Global Registry for the Study of Chronic Total Occlusion Intervention) score. JACC Cardiovasc Interv 2016; 9: 1-9.

24. Karatasakis A, Danek BA, Brilakis ES. Scoring systems for chronic total occlusion percutaneous coronary intervention: if you fail to prepare you are preparing to fail. J Thorac Dis 2016; 8: E1096-9.

25. Karatasakis A, Danek BA, Karmpaliotis D, et al. Comparison of various scores for predicting success of chronic total occlusion percutaneous coronary intervention. Int I Cardiol 2016; 224: 50-6.

26. Baykan AO, Gür M, Acele A, et al. Predictors of successful percutaneous coronary intervention in chronic total coronary occlusions. Adv Interv Cardiol 2016; 12: 17-24.

27. de Castro-Filho A, Lamas ES, Meneguz-Moreno RA, et al. Impact of the occlusion duration on the performance of J-CTO score in predicting failure of percutaneous coronary intervention for chronic total occlusion. J Invasive Cardiol 2017; 29: 195-201.

28. Sharma V, Wilson W, Smith W, et al. Comparison of characteristics and complications in men versus women undergoing chronic total occlusion percutaneous intervention. Am J Cardiol 2017; 119: 535-41.

29. Dębski M, Dębski A, Tyczyński P, et al. Retrograde recanalization of chronic total occlusion. A novel maneuver of the old technique. Adv Interv Cardiol 2017; 13: 82-3.

30. Barlis P, Kaplan S, Dimopoulos K, et al. An indeterminate occlusion duration predicts procedural failure in the recanalization of coronary chronic total occlusions. Catheter Cardiovasc Interv 2008; 71: 621-8. 